\title{
(a) OPEN ACCESS \\ Severe thoracic pyomyositis in a patient with systemic lupus erythematosus
}

\author{
Yu-Ning Kuo (1) , ${ }^{1}$ Chih-Sheng Lai, ${ }^{2}$ Yi-Hsing Chen 다, ${ }^{1}$ Lai Kuo-lung ${ }^{1}$
}

${ }^{1}$ Division of Allergy, Immunology and Rheumatology, Department of Internal Medicine, Taichung Veterans General Hospital, Taichung, Taiwan

${ }^{2}$ Division of Plastic and Reconstructive Surgery, Department of Surgery, Taichung Veterans General Hospital, Taichung, Taiwan

Correspondence to Dr Lai Kuo-lung:

kllaichiayi@vghtc.gov.tw

Accepted 7 January 2022
Check for updates

(c) BMJ Publishing Group Limited 2022. Re-use permitted under CC BY-NC. No commercial re-use. See rights and permissions. Published by BMJ.

To cite: Kuo Y-N, Lai C-S Chen $\mathrm{Y}-\mathrm{H}$, et al. BMJ Case Rep 2022;15:e246484 doi:10.1136/bcr-2021246484

\section{SUMMARY}

Pyomyositis may mimic deep vein thrombosis and be misdiagnosed in patients with systemic lupus erythematosus (SLE). We report here on patient with SLE with severe thoracic pyomyositis presented with right upper arm swelling and fever. The patient fully recovered after a serial surgical debridement and antibiotic therapy. Pyomyositis, as well as deep vein thrombosis, should be considered during the differential diagnosis of patients with SLE experiencing fever and unilateral limb oedema. CT and identification of causal pathogens are crucial in the diagnosis of pyomyositis. Early effective antibiotic treatment as well as surgical intervention can together bring about a better outcome.

\section{BACKGROUND}

Pyomyositis is a pyogenic infection of skeletal muscle with the typical presentation of a localised abscess, which is mostly observed in tropical countries. It commonly affects patients with existing conditions such as diabetes mellitus, haematological malignancy, chronic renal failure, asplenia, HIV infection, autoimmune diseases and those receiving chemotherapy or immunosuppressive drugs. ${ }^{12}$ Pyomyositis is mostly caused by Staphylococcus aureus up to $90 \%$ of the cases. S. aureus is in most cases a community-acquired methicillinresistant strain. ${ }^{3} 4$ Pyomyositis usually affects a single muscle, although the involvement of multiple muscles is not unusual (12\%-40\% of cases). Bulky muscles, particularly of the thigh, are the most commonly infected site. Other muscles, including the forearm, sternocleidomastoid and intercostal muscles are occasionally involved.

Three clinical stages of pyomyositis are known. The first stage is an invasive stage, involving muscle pain with oedema, low-grade fever and general malaise. ${ }^{1}$ The second stage is a suppurative phase, where patients experience severe muscle tenderness and swelling, a high spike in fever and other severe systemic symptoms. During this stage, abscess formation is detectable, and it is when most cases are clinically diagnosed. However, classical signs of an abscess may be absent due to the tense overlying muscles. ${ }^{6}$ If treatment is delayed, the infection disseminates and progresses to the final stage, which is also the most severe stage. During this last stage, patients often experience bacteraemia, septic shock, acute renal failure, multiple abscesses and even death. ${ }^{2}$

The diagnosis of pyomyositis depends on findings obtained from imaging, including ultrasonography, CT and MRI or on pathological findings.
However, it is difficult to diagnose during the early stage due to its non-specific features. Therefore, it is necessary for clinicians to be alert for patients showing risks. Systemic lupus erythematosus (SLE) is a chronic autoimmune disease, which renders patients susceptible to infections due to impaired immunological responses, which are related to the disease itself. $^{7}$ As the disease progresses, when superfluous immune reactivation damages multiple organs in patients with SLE, defence mechanisms fighting against pathogens including bacteria, viruses and fungi become impaired. Initially, white cell function defects play a very important role. Additionally, cytokine abnormalities also influence an SLE patient's susceptibility to infection, including decreased phagocytosis, reduced production of IL-8 and IL-12 by polymorphonuclear leucocytes and complement deficiency as well as defective chemotaxis, membrane recognition and attachment to microorganisms. Third, the presence of antimannose-binding lectin (MBL) autoantibodies in patients with SLE can influence MBL plasma levels and their functional activity. MBL activates the complement system, so the polymorphisms of the MBL-2 gene have been associated with infections. In addition to the disease itself, immunosuppressive agents used to treat SLE, such as steroids and cyclophosphamide are known to predispose patients with SLE to infection. The risk factors for infection are lupus activity state, hypocomplementaemia, use of high-dose steroids and immunosuppressive agents, fever, high-level erythrocyte sedimentation rate and of $\mathrm{C}$ reactive protein (CRP), an abnormality in white blood cell $\left(<4 \times 10^{9} / \mathrm{L}\right.$ or $>10 \times 10^{9} / \mathrm{L}$ ) and a low level of albumin.

Timely diagnosis of pyomyositis in patients with SLE is challenging not only because of its nonspecific features but also due to its mimicry of SLE flare-up and inflammatory myositis. Chest wall involvement is an uncommon condition and has been identified in only one of 25 reported SLE cases with pyomyositis in the available literature. ${ }^{7-31}$ Here, we have reported on a case of SLE with a large extent of chest wall pyomyositis, where the patient fully recovered after surgical intervention and antibiotic treatment.

\section{CASE PRESENTATION}

A 64-year-old woman with SLE was admitted to our hospital due to progressive pain in the right lower neck, painful swelling at the right shoulder for 3 days as well as fever without chills for 1 day. She had received acupuncture over the right shoulder 2 days prior to the onset of fever. She denied any 


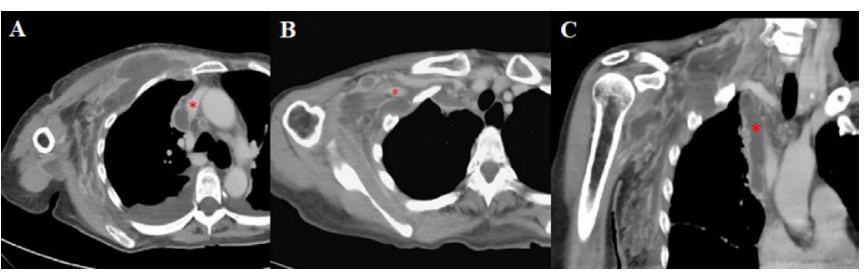

Figure 1 Axial views ( $A$ and $B$ ) and sagittal view (C) obtained from multidetector CT on hospital day 8. They demonstrate (A) large area of an abscess formation over inner part of the right upper chest wall, particularly the pectoralis muscles, which also compressed to the right lateral part of superior vena cava (star); (B) abscess compressed to distal end of the right subclavian vein (star); (C) abscess extended to right lower neck and mediastinum (star)

history of strenuous exercise or contact with any febrile individuals. She had been diagnosed with SLE 20 years prior at the age of 44 with initial presentations of Raynaud phenomenon, photosensitive rash, positive antinuclear antibody, positive antidouble-strandard DNA antibody, low complement, positive lupus anticoagulant and positive anti-Sjögren's syndrome-related antigen A ntibody. She had been taking azathioprine at $25 \mathrm{mg} /$ day during the last year just prior to this admission.

On admission, her vital signs were temperature $39.9^{\circ} \mathrm{C}$, pulse $120 \mathrm{bpm}$, blood pressure $83 / 47 \mathrm{~mm} \mathrm{Hg}$ and respiratory rate $26 /$ min. Her body weight was $56 \mathrm{~kg}$. A physical examination revealed swelling and tenderness without erythematous changes over her right lower neck and shoulder, along with limited movement of the right shoulder and neck. The overlying skin was warm and no neck lymphadenopathy was palpable. There was no active cutaneous or mucosal sign of lupus, no arthritis and no leg oedema. Blood laboratory examinations revealed a white cell count of $2810 / \mu \mathrm{L}$ (normal range $(\mathrm{N})$ : 3900-11 000), haemoglobin $8.8 \mathrm{~g} / \mathrm{dL}\left(\mathrm{N}: 13.5-17.5 \mathrm{~g} / \mathrm{dL}\right.$ ), platelet count $613 \times 10^{9} / \mathrm{L}$ $\left(\mathrm{N}: 150-400 \times 10^{9} / \mathrm{L}\right)$, total bilirubin $4.29 \mathrm{mg} / \mathrm{dL}(\mathrm{N}: 0.2-1.2 \mathrm{mg} /$ $\mathrm{dL}$ ), albumin $2.6 \mathrm{~g} / \mathrm{dL}(\mathrm{N}: 3.3-5.0 \mathrm{~g} / \mathrm{dL})$, prothrombin time $14.6 \mathrm{~s}(\mathrm{~N}: 9.5-11.7 \mathrm{~s})$, activate partial thromboplastin time $47 \mathrm{~s}$ (N: 24.3-32.7s), blood urea nitrogen $33 \mathrm{mg} / \mathrm{dL}$ (N: $5-25 \mathrm{mg} /$ $\mathrm{dL}$ ), creatinine $1.25 \mathrm{mg} / \mathrm{dL}(\mathrm{N}: 0.5-0.9 \mathrm{mg} / \mathrm{dL})$, sodium 126 $\mathrm{mEq} / \mathrm{L}(\mathrm{N}: 137-153 \mathrm{mEq} / \mathrm{L})$, potassium $3.4 \mathrm{mEq} / \mathrm{L}(\mathrm{N}: 3.5-5.3$ $\mathrm{mEq} / \mathrm{L})$, creatine kinase $587 \mathrm{U} / \mathrm{L}(\mathrm{N}: 10-160 \mathrm{U} / \mathrm{L})$, lactate: $19.8 \mathrm{mg} / \mathrm{dL}(\mathrm{N}: 3-12 \mathrm{mg} / \mathrm{dL}), \mathrm{CRP} 24.3 \mathrm{mg} / \mathrm{dL}(\mathrm{N}:<0.3 \mathrm{mg} / \mathrm{dL})$

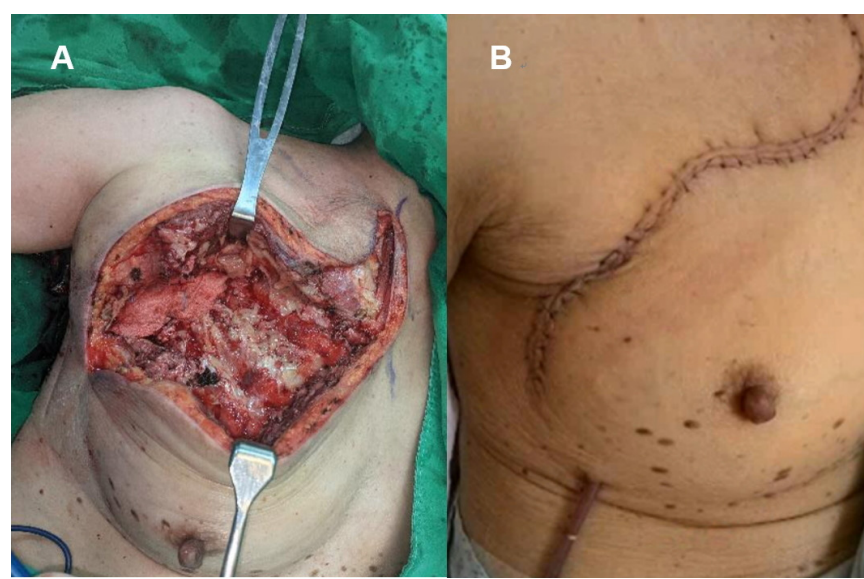

Figure 2 (A) Intraoperative photography showed a partially necrotic pectoralis major muscle and presence of extensive necrotic tissues between the pectoralis minor and major muscles. (B) The surgical wound was sutured on hospital day 22 , with a tubing put in place for continuous drainage.

and procalcitonin $42.53 \mathrm{ng} / \mathrm{mL}(<0.05 \mathrm{ng} / \mathrm{mL})$. The high levels of CRP and procalcitonin indicated an active infection. AntidsDNA, complement C3 and C4, immunoglobulin G, lactate dehydrogenase and thyroid function were all within normal limits. The antiphospholipid profile revealed positive lupus anticoagulant, negative anticardiolipin and negative anti- 32 glycoprotein 1. A urine protein test was negative, while her SLE disease activity was low.

A chest radiograph and sonogram indicated pleural effusion on the right side. Pleural fluid analysis revealed it to be exudative in nature and the subsequent pleural fluid culture yielded no signs of bacterial growth. An urgently needed non-contrast CT scan revealed a small heterogeneous low-density lesion at the right lower neck, diffuse edematous changes in the right anterior and lateral chest wall with fat stranding. A musculoskeletal ultrasonography showed a decrease in echogenicity at the anterior scalene muscles with a loss of normal muscle texture. Image findings were consistent with pyomyositis without a liquified abscess. We initiated fluid resuscitation, vasopressor, parenteral empirical antibiotic treatments with cefotaxime at $2 \mathrm{~g}$ every 12 hours and vancomycin at $1 \mathrm{~g}$ every 12 hours for septic shock.

\begin{tabular}{|c|c|c|c|c|}
\hline & & External compression to vein (eg, abscess) $)^{38-40}$ & Deep vein thrombosis ${ }^{39} 40$ & Lymphangitis $^{33-37}$ \\
\hline \multirow[t]{3}{*}{ Clinical manifestation } & Swelling or oedema & Upper extremity/lower extremity* & Lower extremity $\dagger$ & Lower extremity \\
\hline & Pain & + & $+l-\ddagger$ & - \\
\hline & Fever & $+/-\S$ & - & - \\
\hline \multirow[t]{3}{*}{ Laboratory } & D-dimer & - & + & - \\
\hline & CRP/ESR & + & - & $+1-$ \\
\hline & APS profile & - & +9 & - \\
\hline Therapy & & Removal of lesion & Anticoagulation & Steroids \\
\hline
\end{tabular}

*Pyomyositis most often occur in the lower extremity, including the thigh, calf and gluteal muscles, although any muscle group can be involved, including the upper extremity muscles.

tOnly 4\%-10\% of all deep vein thromboses were located in the upper extremities. Lower extremity deep vein thrombosis was diagnosed in the range of $20 \%-30 \%$ for patients with APS seen in large cohort studies.

¥Pain was felt in $86 \%$ and $19 \%$ of patients diagnosed with deep vein thrombosis.

§In clinical stage 1, fever may not be detected, but is often observed in clinical stage 2, which occurs 10-21 days after the initial onset of symptoms.

IThirty two per cent $(21 / 66)$ of patients with positive lupus anticoagulant (LA) and/or positive anticardiolipin antibodies (aCLs) were diagnosed with deep vein thrombosis.

Patients with $\mathrm{LA}+/ \mathrm{aCL}+$ showed a higher prevalence of DVT $(53 \%)$ as compared with $\mathrm{LA}+/ \mathrm{aCL}-(27 \%)$ and $\mathrm{LA}-/ \mathrm{aCL}+(22 \%)$.

APS, antiphospholipid syndrome; CRP, C reactive protein; ESR, erythrocyte sedimentation rate; SLE, systemic lupus erythematosus. 


\begin{tabular}{|c|c|c|c|c|c|c|}
\hline Number & Reference/year & Age (years) & Symptoms at presentation & Lesion location & Therapy & Outcome \\
\hline 1 & Ushijima et al/1985 ${ }^{10}$ & 14 & $\begin{array}{l}\text { Fever } \\
\text { Swelling }\end{array}$ & Quadriceps, Gluteal & $\begin{array}{l}\text { Antibiotics } \\
\text { ID }\end{array}$ & Recovery \\
\hline 2 & Shames and Fast $/ 1989^{8}$ & 59 & $\begin{array}{l}\text { Fever } \\
\text { Pain }\end{array}$ & Gluteal & $\begin{array}{l}\text { Antibiotics } \\
\text { ID }\end{array}$ & Recovery \\
\hline 3 & Shamiss et al/1990"11 & 19 & $\begin{array}{l}\text { Fever } \\
\text { Swelling } \\
\text { Pain } \\
\text { Oedema }\end{array}$ & Posterior thighs, calves & $\begin{array}{l}\text { Antibiotics } \\
\text { ID }\end{array}$ & Recovery \\
\hline 4 & Bonafede et al/ $/ 1992^{13}$ & 31 & $\begin{array}{l}\text { Swelling } \\
\text { Pain }\end{array}$ & Upper arm, thigh & $\begin{array}{l}\text { Antibiotics } \\
\text { ID }\end{array}$ & Recovery \\
\hline 5 & Dede et al/1993 ${ }^{28}$ & 23 & Swelling & Calf & Antibiotics & Recovery \\
\hline 6 & Yoshino et al $/ 1994^{9}$ & 44 & Pain & Glutaeal & $\begin{array}{l}\text { Antibiotics } \\
\text { ID }\end{array}$ & Recovery \\
\hline 7 & Belzunegui et al/1995 ${ }^{15}$ & 27 & $\begin{array}{l}\text { Fever } \\
\text { Pain } \\
\text { Palpable mass }\end{array}$ & Erector spinae & Antibiotics & Recovery \\
\hline 8 & Gordon et al/1995 $5^{12}$ & 48 & Fever & $\begin{array}{l}\text { Pectoralis major and minor, } \\
\text { subclavius, intercostal muscles }\end{array}$ & Antibiotics & Death \\
\hline 9 & Claudepierre et al/1996 ${ }^{16}$ & 32 & $\begin{array}{l}\text { Fever } \\
\text { Pain } \\
\text { Swelling }\end{array}$ & Quadriceps & $\begin{array}{l}\text { Antibiotics } \\
\text { ID }\end{array}$ & Recovery \\
\hline 10 & Ushida et al/20017 & 21 & Pain & Psoas & $\begin{array}{l}\text { Antibiotics } \\
\text { ID }\end{array}$ & Death \\
\hline 11 & Teh et al/2002 ${ }^{18}$ & 25 & NA & Thigh, calf & NA & Recovery \\
\hline 12 & García Hernández et al/2003 ${ }^{19}$ & 33 & $\begin{array}{l}\text { Fever } \\
\text { Pain }\end{array}$ & Iliopsoas & $\begin{array}{l}\text { Antibiotics } \\
\text { ID }\end{array}$ & Recovery \\
\hline 13 & Jidpugdeebodin and Punyagupta/2004 ${ }^{29}$ & 31 & NA & Shoulder, axilla, arm, forearm & NA & Recovery \\
\hline 14 & Ravindran and Duke $/ 2009^{20}$ & 34 & $\begin{array}{l}\text { Fever } \\
\text { Pain } \\
\text { Swelling }\end{array}$ & Pronator teres & Antibiotics & Recovery \\
\hline 15 & Collier et al/201021 & NA & $\begin{array}{l}\text { Fever } \\
\text { Pain } \\
\text { Swelling }\end{array}$ & Sternocleidomastoid & Antibiotic & Recovery \\
\hline 16 & El Baaj et al/201022 & 47 & $\begin{array}{l}\text { Fever } \\
\text { Pain }\end{array}$ & Quadriceps & $\begin{array}{l}\text { Antibiotics } \\
\text { ID }\end{array}$ & Recovery \\
\hline 17 & Manzoor $/ 2010^{30}$ & 23 & NA & Rectus femoris & NA & Recovery \\
\hline 18 & Sokolove et al $/ 2010^{23}$ & 39 & $\begin{array}{l}\text { Fever } \\
\text { Pain }\end{array}$ & Quadriceps & Antibiotics & Recovery \\
\hline 19 & Souza et al/ $/ 2011^{24}$ & 25 & $\begin{array}{l}\text { Fever } \\
\text { Pain }\end{array}$ & lliacus & $\begin{array}{l}\text { Antibiotics } \\
\text { ID }\end{array}$ & Recovery \\
\hline 20 & Blay et al/2014 25 & 16 & $\begin{array}{l}\text { Fever } \\
\text { Pain }\end{array}$ & Vastus intermedius & Antibiotics & Recovery \\
\hline 21 & Chebbi et al/2014 26 & 52 & $\begin{array}{l}\text { Fever } \\
\text { Pain }\end{array}$ & Iliacus, glutaeal & Antibiotics & Recovery \\
\hline 22 & Simopoulou et al/2014 27 & 46 & $\begin{array}{l}\text { Fever } \\
\text { Pain } \\
\text { Swelling } \\
\text { Ulcer with purulent discharge. }\end{array}$ & Vastus lateralis & $\begin{array}{l}\text { Antibiotics } \\
\text { ID }\end{array}$ & Recovery \\
\hline 23 & Meesiri S/2016 & 14 & $\begin{array}{l}\text { Fever } \\
\text { Pain }\end{array}$ & Gastrocnemius & $\begin{array}{l}\text { Antibiotics } \\
\text { ID }\end{array}$ & Recovery \\
\hline 24 & Modi MA et al/2013 $3^{31}$ & 45 & Swelling & Quadriceps & $\begin{array}{l}\text { Antibiotics } \\
\text { ID }\end{array}$ & Recovery \\
\hline 25 & Chen YH et al/ $/ 2018^{14}$ & 48 & $\begin{array}{l}\text { Pain } \\
\text { Swelling }\end{array}$ & Flexor hallucis, flexor digitorum. & $\begin{array}{l}\text { Antibiotics } \\
\text { ID }\end{array}$ & Recovery \\
\hline
\end{tabular}

ID, incision and drainage; NA, not available.

On hospital day 5 , her vital signs became stable, but she had an intermittent low-grade fever and progressive right upper limb edematous changes without erythema. However, there was no turning pale, pulseless, nor did she experience any numbness. Four sets of blood cultures were taken, all of which yielded no bacterial growth.
Because her progressive right upper limb oedema was suspected to be due to deep vein thrombosis, a multidetector CT (MDCT) was performed on hospital day 8. Those results revealed an extensive abscess at the pectoralis muscle with adjacent fat stranding. The abscess extended upward to the right lower neck (levator scapulae muscle) and the mediastinum as 
well as down to the right deep lateral thoracic wall (intercostal muscles).

Notably, the abscess had compressed the superior vena cava and right subclavian vein, but no evidence of deep vein thrombosis was found (figure 1). A fasciotomy involving drainage and debridement was performed on the same hospital day as the MDCT, day 8. Extensive necrotic tissues were observed at the pectoralis minor and major muscles (figure 2). Negative pressure wound therapy (NPWT) was also applied. A pus culture yielded methicillin-resistant $S$. aureus. Vancomycin was prescribed for 28 days in order to control infection. Serial debridements were performed in combination with continuous NPWT for a span of 2 weeks. The patient's symptoms improved, including right lower neck and right upper limb swelling, and were completely resolved 6 days after the first debridement. The surgical wound was sutured on hospital day 22, with tubing put in place for drainage. Beginning on hospital day 29, antibiotics were switched to oral linezolid at $600 \mathrm{mg}$ every 12 hours. She was discharged on hospital day 33.

Her condition remained stable during subsequent outpatient department (OPD) visits, with the drainage tubing being later removed. A follow-up CT scan performed 3 weeks after discharge showed a complete resolution of both the chest wall abscess and mediastinal abscess. The antibiotic linezolid was finally discontinued. No recurrence of pyomyositis was noted during OPD follow-up visits over the next 3 months.

\section{DISCUSSION}

Pyomyositis is an infection primarily involving skeletal muscles. The evolution of myositis could be clinically classified into three stages. In the first stage, non-specific symptoms may be complained of, including focal muscle pain with a wooden consistency, erythema, oedema, low-grade fever and general malaise, while many differentials should be concerning, including thrombotic events, haematoma, muscle strain and osteomyelitis. Our patient experienced progressive warmth, swelling and oedema without erythema over her right lower neck and right upper limb and a mimicking of classic symptoms for deep vein thrombosis. Positive findings for phospholipid antibodies occur in up to $40 \%$ of patients with SLE. A significant proportion of patients with SLE is also diagnosed with primary Antiphospholipid syndrome. ${ }^{32}$ Pyomyositis should also be differentially diagnosed for patients with SLE. Another differential diagnosis given patients with SLE with unilateral limb oedema is lymphangitis. ${ }^{33-37}$ The comparison between external compression to vein (eg, abscess), ${ }^{38-40}$ deep vein thrombosis and lymphangitis is shown in table 1.

Regarding pyomyositis, up to $90 \%$ of patients are diagnosed at the second stage, also known as the purulent stage. ${ }^{7}$ However, during this stage, a lack of specific signs and symptoms as well as atypical manifestations may also be observed in patients with SLE. ${ }^{5041-43}$ In SLE child patients, pyomyositis is extremely rare with a prevalence of only $0.35 \%(1 / 289) .{ }^{25}$ However, the prevalence of pyomyositis in adult patients with SLE remains unclear. The diagnosis of pyomyositis is sometimes delayed or even missed due to its unfamiliarity to physicians. Any or all adverse conditions could result in high rates of complications and morbidity. Therefore, obtaining a timely diagnosis of pyomyositis in patients with SLE can be fraught with challenges. For a clinician, pyomyositis should be taken as a differential diagnosis for patients with an immunosuppression and immunocompromised state, like SLE. Imaging assessments, including ultrasonography, CT scans and MRIs, are important in diagnosing pyomyositis. Ultrasonography is a simple, easily available, non-radiative imaging tool used for diagnosis, although it may miss spotting early myositis, deep muscle abscess or lesions, where its ultrasound beam fails to detect. Alternatively, a contrast-enhanced CT scan and MRI can provide a comprehensive assessment of muscle lesions. If clinical symptoms, including fever, local oedema, swelling and erythematous change, do not improve after empirical antibiotics treatment, repeating an image study, such as a CT scan, is necessary for both detection of disease progression and determining the time when surgical intervention becomes necessary. Regarding our present case, the first CT scan showed no abscess formation in the chest wall. However, a subsequent CT scan performed 7 days later revealed the extensive involvement of pyomyositis with abscess formations. An accurate assessment of the location and extent of muscle abscess is essential for both proper treatment and preoperative planning.

For pectoralis pyomyositis, particularly in stages 2 and 3, further management should include not only immediate and appropriate antibiotics therapy according to the culture of the purulent materials but also early drainage of any purulent discharge as well as surgical debridement. Our patient's clinical condition improved rapidly after surgical intervention when compared with antibiotics treatment alone. A similar case report on a 48-year-old SLE diagnosed woman with chest wall pyomyositis revealed that she had received antibiotics treatment, CT-guided aspiration and drainage of her abscess. She died due to pneumonia and sepsis while experiencing with multiple organ failure. ${ }^{12}$ Other clinical features and therapies surrounding 25 cases of patients with SLE with pyomyositis are summarised in table 2. In our present case, the patient successfully recovered from severe chest wall pyomyositis after serial debridement and proper antibiotic treatments. This result indicates the importance of surgical intervention in patients with SLE with chest wall pyomyositis. NPWT is a recent wound treatment modality that provides negative suction pressure for the continuous drainage of an abscess and any wound discharge. The therapy could improve wound closure after a fasciotomy has been performed for treating acute compartment syndrome in patients experiencing necrotising fasciitis. The time interval from fasciotomy to wound closure averages 11.8 days for patients with compartment syndrome using NPWT. There is no need for using a skin graft or flap, with no additional morbidity being reported. ${ }^{44}$ Our patient experienced normal, successful wound healing using NPWT after fasciotomy for pyomyositis. The time interval from fasciotomy to wound closure was 14 days.

In conclusion, pyomyositis may mimic deep vein thrombosis and be misdiagnosed in patients with SLE with unilateral limb oedema.

\section{Learning points}

- When a patient with systemic lupus erythematosus (SLE) shows unilateral limb oedema in the presence of fever and warm skin, infections such as an abscess or pyomyositis should be taken into consideration.

- Pyomyositis may mimic deep vein thrombosis and be misdiagnosed in patients with SLE experiencing unilateral limb oedema.

- An imaging assessment such as a CT scan, along with the identification of causal pathogens, is crucial for the diagnosis of pyomyositis.

- Wile regards to pyomyositis, early effective antibiotic treatment and surgical intervention can provide a satisfactory outcome. 
Imaging assessment such as a CT scan and identification of causal pathogens are crucial for diagnosis. A succesfuloutcome depends on early and effective antibiotic treatment as well as surgical intervention.

Contributors C-SL, Y-NK and LK-I provided and cared for study patients. LK-I had the idea for the article and planned the work. LK-I also reviewed the study proposal, edited the article and controlled the decision to publish. C-SL participated in editing of the manuscript. Y-HC performed the literature search, wrote the article and accepted full responsibility for the finished article.

Funding The authors have not declared a specific grant for this research from any funding agency in the public, commercial or not-for-profit sectors.

\section{Competing interests None declared.}

Patient consent for publication Consent obtained directly from patient(s) Provenance and peer review Not commissioned; externally peer reviewed.

Open access This is an open access article distributed in accordance with the Creative Commons Attribution Non Commercial (CC BY-NC 4.0) license, which permits others to distribute, remix, adapt, build upon this work non-commercially, and license their derivative works on different terms, provided the original work is properly cited and the use is non-commercial. See: http://creativecommons.org/ licenses/by-nc/4.0/.

Case reports provide a valuable learning resource for the scientific community and can indicate areas of interest for future research. They should not be used in isolation to guide treatment choices or public health policy.

ORCID iDs

Yu-Ning Kuo http://orcid.org/0000-0003-1334-741X

Yi-Hsing Chen http://orcid.org/0000-0002-8135-9554

\section{REFERENCES}

1 Narayanappa G, Nandeesh BN. Infective myositis. Brain Pathol 2021:31:e12950.

2 Chauhan S, Jain S, Varma S, et al. Tropical pyomyositis (myositis tropicans): current perspective. Postgrad Med J 2004;80:267-70.

3 Ruiz ME, Yohannes S, Wladyka CG. Pyomyositis caused by methicillin-resistant Staphylococcus aureus. N Engl J Med 2005;352:1488-9.

4 Shittu A, Deinhardt-Emmer S, Vas Nunes J, et al. Tropical pyomyositis: an update. Trop Med Int Health 2020;25:660-5.

5 Agarwal V, Chauhan S, Gupta RK. Pyomyositis. Neuroimaging Clin N Am 2011;21:975-83.

6 Habeych ME, Trinh T, Crum-Cianflone NF. Purulent infectious myositis (formerly tropical pyomyositis). J Neurol Sci 2020;413:116767.

7 Meesiri S. Pyomyositis in a patient with systemic lupus erythaematosus and a review of the literature. BMJ Case Rep 2016;2016:bcr2016214809.

8 Shames JL, Fast A. Gluteal abscess causing sciatica in a patient with systemic lupus erythematosus. Arch Phys Med Rehabil 1989;70:410-1.

9 Yoshino YHS, Takeuchi A, Hashimoto T. [Gluteal abscess caused by Staphylococcus aureus in a patient with systemic lupus erythematosus]. Ryumachi 1994;34.

10 Ushijima H, Soda H, Okitsu S, et al. Subcutaneous and / or intramuscular abscesses in two cases of systemic lupus erythematosus. Jpn I Clin Immunol 1985;8:47-53.

11 Shamiss A, Thaler M, Nussinovitch N, et al. Multiple Salmonella enteritidis leg abscesses in a patient with systemic lupus erythematosus. Postgrad Med 1990:66:486-8

12 Gordon BA, Martinez S, Collins AJ. Pyomyositis: characteristics at CT and MR imaging. Radiology 1995;197:279-86.

13 Bonafede P, Butler J, Kimbrough R, et al. Temperate zone pyomyositis. West J Med 1992:156:419-23.

14 Chen Y-H, Lu C-C, Chen H-C. Candida albicans Pyomyositis in a Patient with Systemic Lupus Erythematosus. J Rheumatol 2018;45:286-7.

15 Belzunegui J, Plazaola I, Uriarte E, Pego JM, et al. Primary tuberculous muscle abscess in a patient with systemic lupus erythematosus. Br I Rheumatol 1995:34:1177-8.

16 Claudepierre P, Saint-Marcoux B, Allain J, et al. Clinical images: value of magnetic resonance imaging in extensive pyomyositis. Arthritis Rheum 1996:39:1760.
17 Ushida H, Koizumi S, Katoh K, Okada Y, et al. [Systemic lupus erythematosus presenting as a brainstem infarction and hemorrhage during treating retroperitoneal abscess: a case report]. Nihon Hinyokika Gakkai Zasshi 2001:92:579-82.

18 Teh CL, Kong KO, Chong APY, Badsha H, et al. Mycobacterium haemophilum infection in an SLE patient on mycophenolate mofetil. Lupus 2002:11:249-52.

19 García Hernández FJ, Sánchez Román J, Ocaña Medina C. Absceso del músculo iliopsoas y lupus eritematoso sistémico [lliopsoas abscess and systemic lupus erythematosus]. An Med Interna 2003;20:198-200.

20 Ravindran V, Duke O. Non-Tropical pyomyositis in a patient with systemic lupus erythematosus. Lupus 2009;18:379-80.

21 Collier S, Vig N, Collier J. Two cases of tropical pyomyositis of the sternocleidomastoid muscle occurring in the UK. Br J Oral Maxillofac Surg 2010;48:216-7.

22 El Baaj FT M, Modden K, Hassikou H. La pyomyosite : une complication infectieuse du lupus érythémateux systémique [Pyomyositis: an infectious complication in systemic lupus erythematous]. La Revue de Médecine Interne 2010;31:e4-6.

23 Sokolove J, Copland A, Shirvani S, et al. A 39-year-old woman with lupus, myositis, and a recalcitrant vasculopathy. Arthritis Care Res 2010;62:1351-6.

24 Souza HCBde, Carvalho BNde, Morais MGVde, et al. Tropical pyomyositis in a patient with systemic lupus erythematosus and HTLV 1/2 infection. Rev Bras Reumatol 2011:51:97-103.

25 Blay G, Ferriani MPL, Buscatti IM, et al. Pyomyositis in childhood-systemic lupus erythematosus. Rev Bras Reumatol Engl Ed 2016;56:79-81.

26 Chebbi W, Jerbi S, Kessomtini W, et al. Pyogenic sacroiliitis and pyomyositis in a patient with systemic lupus Erythematous. Case Rep Rheumatol 2014:2014:1-4.

27 Simopoulou T, Varna A, Dailiana Z, et al. Tuberculous pyomyositis: a re-emerging entity of many faces. Clin Rheumatol 2016;35:1105-10.

28 Dede H, Ozdoğan H, Dumankar A, et al. Tropical pyomyositis in a temperate climate. Br J Rheumatol 1993;32:435-6.

29 Jidpugdeebodin S, Punyagupta S. Salmonella Crepitant pyomyositis in a patient with systemic lupus erythematosus. I Infect Dis Antimicrob Agents2004;21:11-15.

30 Manzoor K. A 'tropical disease' in an immunocompromised patient.. Darlington County Durham Med J2010;4:7-9.

31 Modi MA, Mate AD, Nasta AM, et al. Primary tuberculous pyomyositis of quadriceps femoris in an immunocompetent individual. Case Rep Infect Dis 2013;2013:723879.

32 Meroni PL, Tsokos GC. Editorial: systemic lupus erythematosus and antiphospholipid syndrome. Front Immunol 2019;10:199.

33 Ye J, Zhou Z, Teng J, et al. Lymphoedema of lower limbs in systemic lupus erythematosus. BMJ 2019:1970

34 Rajasekhar L, Habibi S, Sudhakar P, et al. Lymphatic obstruction as a cause of extremity edema in systemic lupus erythematosus. Clin Rheumatol 2013;32 Supp 1:11-13.

35 Pittau E, Tinti A, Martini L, Bogliolo A, et al. Systemic lupus erythematosus with pitting oedema of the distal lower limbs. Br I Rheumatol 1998;37:104-5.

36 Whitfield A. Disseminated lupus with chronic lymphangitis of the face and osteoarthritis of the hands. Proc $R$ Soc Med 1908;1:93-4

37 Günaydin I, Daikeler T, Mohren M, et al. Lower limb pitting edema in systemic lupus erythematosus. Rheumatol Int 1999;18:159-60.

38 Shepherd JJ. Tropical myositis: is it an entity and what is its cause? Lancet 1983:2:1240-2

39 Cervera R, Piette J-C, Font J, et al. Antiphospholipid syndrome: clinical and immunologic manifestations and patterns of disease expression in a cohort of 1,000 patients. Arthritis Rheum 2002;46:1019-27.

40 Cervera R, Khamashta MA, Shoenfeld Y, et al. Morbidity and mortality in the antiphospholipid syndrome during a 5-year period: a multicentre prospective study of 1000 patients. Ann Rheum Dis 2009:68:1428-32.

41 Al-Khazraji A, Takher J, Alkhawam H, et al. Primary tuberculous pyomyositis of the calf muscles. Am J Med Sci 2017:353:187-8.

42 Simmers TA, van den Bosch J, Vasmel WL. Tropical pyomyositis in a temperate climate: a case report. Neth J Med 1996;49:86-9.

43 Sciascia S, Cuadrado MJ, Karim MY. Management of infection in systemic lupus erythematosus. Best Pract Res Clin Rheumatol 2013;27:377-89.

44 Eceviz E, Cevik HB. Shoelace technique plus negative-pressure wound therapy closure in fasciotomy wounds. Adv Skin Wound Care 2020;33:497-500.

45 Lee JY, Jung $\mathrm{H}$, Kwon $\mathrm{H}$, et al. Extended negative pressure wound therapy-assisted dermatotraction for the closure of large open fasciotomy wounds in necrotizing fasciitis patients. World J Emerg Surg 2014:9:29. 
Copyright 2022 BMJ Publishing Group. All rights reserved. For permission to reuse any of this content visit https://www.bmj.com/company/products-services/rights-and-licensing/permissions/

BMJ Case Report Fellows may re-use this article for personal use and teaching without any further permission.

Become a Fellow of BMJ Case Reports today and you can:

- Submit as many cases as you like

- Enjoy fast sympathetic peer review and rapid publication of accepted articles

Access all the published articles

- Re-use any of the published material for personal use and teaching without further permission

Customer Service

If you have any further queries about your subscription, please contact our customer services team on +44 (0) 2071111105 or via email at support@bmj.com.

Visit casereports.bmj.com for more articles like this and to become a Fellow 